\title{
GERAKAN ECOTON DALAM UPAYA PEMULIHAN SUNGAI BRANTAS
}

\author{
Miatus Sholikhah ${ }^{1}$, Siti Zunariyah ${ }^{2}$ \\ Program Studi Sosiologi Fakultas Ilmu Sosial dan Politik \\ Universitas Sebelas Maret Surakarta Indonesia \\ Email1: miatussholikhah@gmail.com,Email²: zunariyah@gmail.com
}

\begin{abstract}
Most of Indonesia's rivers fall into the heavily polluted category. One of the heavily polluted rivers in Indonesu is the Brantas River. This research had purpose to understanding the problems in Brantas River and also to know the environmental movement in order to recovering Brantas River. The theory which was used in this research was New Social Movement theory from Rajendra Singh. This research was qualitative research with etnography methods. Data was obtained by observation, detailed interview, and also documentation. The subject of this research was Ecoton, the public accompanied by Ecoton on the headwaters and the downstream of the Brantas River, and the school accompanied by Ecoton. Researcher was using source triangulation techniques to test the collected data legitimation. Researcher used Miles and Huberman's outlook in data analysis, which consist of three activity lines; data reduction, data presentation and draw conclusions.

Results show that there were many problems happened in Brantas River from the headwaters to the downstream. There were five problems found in this research. First, problems in Brantas River headwaters was reclaiming the land functions and illegal logging. Second, there were many abandoned buildings on the riverside. Third, domestic pollution from household. The buildings which were built on the riverside had made the people to easily throw away their garbages to the Brantas River. Mostly it was diapers, which could endanger human and the fishes whom lives in Brantas River. Fourth, the industrial pollution which already exceeds the permittable treshold. Industry had oftenly disposed their waste to the river without conducted the sewage management procedure which then created the new problems in Brantas River: a mass death fish. A mass death fish had become the fifth problems in Brantas River. The damage of environmental condition of Brantas River had pushed the movement from Ecoton. In their movement, Ecoton had the characteristic new social movement which was the ideology of care to the Brantas River damage. The strategy which was used by Ecoton were conducted partitions research, environmental education, advocation and also involved the media on every movement they had done. Ecoton had the non-institutional structure, which was unconcerned with power but put their focus to reach the aims and the visions. Keywords: Environmental Movements, Participation, Environmental Education, Advocacy.
\end{abstract}

Abstrak: Sungai di Indonesia sebagian besar masuk dalam kategori tercemar berat. Salah satu sungai yang tercemar berat di Indonesia adalah Sungai Brantas. Penelitian ini bertujuan untuk mengetahui permasalahan di Sungai Brantas serta mengetahui gerakan lingkungan yang dilakukan untuk pemulihah Sungai Brantas. Teori yang digunakan dalam penelitian ini adalah teori gerakan sosial baru dari Rajendra Singh. Jenis penelitian ini adalah kualitatif dengan metode etnografi. Data didapatkan dengan cara observasi, wawancara mendalam, dan dokumentasi. Subyek penelitian ini adalah Ecoton, masyarakat dampingan Ecoton di bagian hulu dan hilir Sungai Brantas, dan sekolah dampingan Ecoton. Untuk menguji keabsahan data yang telah terkumpul, peneliti menggunakan teknik triangulasi sumber. Dalam Analisa data 
peneliti menggunakan pandangan Miles dan Huberman yang terdiri dari tiga alur kegiatan, yaitu reduksi data, penyajian datam dan menarik kesimpulan.

Dari hasil penelitian ditemukan permasalahan-permasalah yang terjadi di Sungai Brantas mulai dari hulu hingga hilir sungai. Terdapat lima masalah yang ditemukan dalam penelitian ini. Pertama, masalah di hulu Sungai Brantas adalah alih fungsi lahan dan illegal logging. Kedua, maraknya bangunan liar yang berdiri dibantaran sungai, ketiga, pencemaran domestik yang berasal dari rumah tangga. Pendirian bangunan di bantaran sungai memudahkan masyarakat untuk membuang sampah domestik ke Sungai Brantas. Sampah yang dominan dibuang ke Sungai Brantas adalah sampah popok, dampak dari sampah popok dapat membahayakan manusia dan ikan di Sungai Brantas. Keempat adalah pencemaran limbah industri yang melebihi baku mutu. Seringnya industri membuang limbahnya ke sungai tanpa melalui pengelolaan limbah sesuai prosedur menimbulkan masalah baru yaitu ikan mati masal. Masalah ikan mati massal ini menjadi masalah yang kelima di Sungai Brantas. Rusaknya kondisi lingkungan Sungai Brantas mendorong adanya gerakan dari Ecoton. Dalam gerakannya Ecoton mempunyai ciri gerakan sosial baru yaitu ideologi kepedulian atas kerusakan Sungai Brantas. Strategi yang dilakukan ecoton adalah melakukan penelitian partisipatif, edukasi lingkungan, dan advokasi serta melibatkan media dalam setiap gerakan yang dilakukan. Ecoton mempunyai struktur non-institusional, yang tidak mementingkan kekuasaan tetapi lebih pada tercapainya tujuan dan visi misi.

Kata Kunci: Gerakan Lingkungan, Partisipasi, Edukasi Lingkungan, Advokasi.

\section{PENDAHULUAN}

Pengelolaan sungai di Indonesia dari 51 sungai yang dipantau, sebesar 62,74\% masuk kategori tercemar berat, 31,37\% tercemar sedang-berat, 3,92\% tercemar ringan-sedang dan hanya ada satu sungai yang memenuhi standar baku mutu. Dari data yang didapat secara keseluruhan yaitu sekitar 98\% sungai di Indonesia dapat disimpulkan dalam keadaan tercemar berat (Pusarperdal : 2011). Salah satu sungai yang tercemar berat di Indonesia adalah Sungai Brantas. Wilayah Sungai Brantas merupakan wilayah sungai strategis nasional dan menjadi kewenangan Pemerintah Pusat berdasarkan Permen PU No.11 A Tahun 2006. Sungai Brantas merupakan sungai terbesar kedua di Pulau Jawa dan terpanjang yang ada di provinsi Jawa Timur. Panjangnya yaitu mencapai sekitar $320 \mathrm{~km}$, dengan daerah aliran seluas sekitar $12.000 \mathrm{~km}^{2}$ yang mencakup kurang lebih 25\% luas provinsi Jawa Timur yang melewati 17 wilayah kota/ kabupaten Jawa Timur (BBWS Brantas : 2011).

Sungai Brantas berperan cukup besar dalam menunjang Provinsi Jawa Timur sebagai lumbung pangan nasional. Air kali Brantas juga menghasilkan listrik 1 milyar kWh pertahun, menyediakan air baku untuk industri $144 \mathrm{~m}^{3}$ dan PDAM 243 juta $\mathrm{m}^{3}$ pertahun, pariwisata, pertambangan dan penggalian, sarana media belajar, dan ruah bagi keanekaragaman hayati seperti ratusan serangga yang berperan penting dalam penyerbukan, puluhan burung, 25 jenis sebagainya. Potensi air yang tersedia di WS kali Brantas adalah 13,232 milyar meter kubik per tahun, dimana telah digunakan sebesar 3,7 - 4 milyar $\mathrm{m}^{3}$ atau sekitar 28,24 persen, untuk keperluan irigasi, air rumah-tangga, perkotaan dan industri. Sisanya lebih dari 9,532 milyar $\mathrm{m}^{3}$ per tahun atau seitar 71,7 persen masih terbuang ke laut (BBWS Brantas: 2011).

Menurut Dewan Daerah Wahana Lingkungan Hidup (Walhi) Jawa Timur, Purnawan D Negara, sekitar 80 persen pencemaran yang terjadi di sepanjang aliran Sungai Brantas di bagian hulu disebabkan limbah domestik rumah tangga, selebihnya limbah industri, rumah sakit, hotel dan restoran. Namun, setelah memasuki daerah hilir yang masuk wilayah Mojokerto-Surabaya, pencemaran yang disebabkan limbah industri mencapai 50 persen. Selebihnya limbah domestik, Purnawan, yang juga pakar hukum lingkungan Universitas 
Widya Gama Malang. Salah satu sampah yang mendominasi di Sungai Brantas adalah sampah popok bayi, salah satu pemicu pembuangan sampah popok bayi ke sungai adalah mitos yang berkembang di masyarakat, membuang popok bekas yang berujung pada tindakan pembakaran dipercaya akan mengakibatkan kulit di pangkal paha dan pantat bayi menjadi merah seperti luka bakar, atau populer disebut suleten. Akan tetapi dampak yang di timbulkan oleh sampah popok bayi bukan hanya pada kualitas air saja, tetapi pada ikan yang hidup di Sungai Brantas juga terkontaminasi mikroplastik akibat memakan material plastik dari bahan popok. Bahan baku penyusun popok seratus persen adalah bahan berbahaya dan beracun (B3) yang memiliki dampak serius bagi kesehatan balita dan mencemari ekosistem dan biota perairan. (ECOTON : 2018).

Kawasan hiilir Sungai Brantas merupakan daerah aliran Sungai yang paling buruk karena masih ada pencemaran yang terjadi, wilayah ini adalah Mojokerto hingga Surabaya, di wilayah ini banyak perusahaan yang beberapa diantaranya masih belum memiliki instalasi pengelolaan air dan limbah (IPAL). Ada sekitar 70 persen yang berpotensi mengaluarkan limbar cair, beberapa diantaramya adalah pabrik tahu, industry pengelolaan logam dan tekstil yang langsung megalirkan limbar tersebut ke sungai (Jawa Pos : 2018). Salah satu NGO yang terlibat dalam pemulihan Sungai Brantas adalah ECOTON. Yayasan ini telah banyak melakukan aktivitas-aktivitas yang bertujuan untuk memperbaiki kondisi Sungai Brantas yang tercemar. Dalam menanggulangi kerusakan lingkungan, Ecoton mendidik masyarakat untuk sadar lingkungan, melakukan penelitian terhadap kualitas air, memeberikan teguran terhadap pihak-pihak yang berpengaruh dalam tindak pencemaran dan melakukan program pendampingan masyarakat mengenai lingkungan. Ecoton juga melakukan gugatan kepada Pemerintah Daerah Provinsi (Gubernur) karena berdasarkan hasil penelitiannya mendapati bahwa air di Kali Surabaya tidak layak untuk dikonsumsi (Erfan: 2009).

Kehadiran Ecoton dalam persoalan pencemaran air yaitu sebagai kontrol social atas pelaksanaan kebijakan pemerintah. Ecoton juga mengawasi gerak gerik industry dalam mematuhi peraturan yang ada (Singgih. 2015). Selain itu Ecoton juga melakukan gugatan terhadap Pemerintah Provinsi Jawa Timur karena lalai melakukan perhitungan dan penetapan kelas air dan daya tamping beban pencemaran air yang merupakan langkah penting dalam pengelolaan kualitas air yang sudah tercemar (Margaretha : 2017).

Melalui penelitian partisipatif yang dilakukan, Ecoton juga berusaha mengkomunikasikan hasil penelitiannnya kepada masyarakat melalui media cetak maupun elektronik. Dengan diinformasikannya hal tersebut diharapkan masyarakat menjadi tahu dan pada akhirnya masyarakat ikut berpartisipasi untuk menjaga lingkungan. Selain melakukan kajian ilmiah kegiatan yang dilakukan Ecoton diantaranya adalah wisata limbah menyusuri sungai terkhir, aksi dalam hal menyadarkan warga agar tak menjadikan sungai sebagai tempat membuang segala macam sampah, aksi kampanye social dalam memperingati hari lingkungan, kegiatan river ranger, pendampingan dan pemberdayaan masyarakat dalam mengelola lingkungan (Mochammad : 2015).

Selain itu masih ada beragam upaya yang dilakukan Ecoton dalam pemulihan Sungai Brantas, dalam menjalankan upaya nya tersebut tentu saja tidak bejalan dengan lancar dan banyak hambatan yang dihadapi oleh Ecoton. Hal tersebut adalah yang melatarbelakangi peneliti dalam melakukan penelitian tentang gerakan Ecoton dalam upaya pemulihan Sungai Brantas. Berdasarkan latar belakang diatas maka rumusan masalah yang diambil adalah Apa saja permasalahan yang ada di Sungai Brantas ? dan Bagaimana gerakan Ecoton dalam upaya pemulihan Sungai Brantas? 


\section{METODE PENELITIAN}

Penelitian ini dilakukan di LSM Ecoton (Ecological Obsevasi And Wetlands Conversation) yang merupakan lembaga swadaya masyarakat lingkungan dan lembaga penelitian lingkungan hidup independen yang berdiri sejak tahun 1996 yang peduli dan juga pemerhati lingkungan khususnya Sungai Brantas. LSM Ecoton beralamatkan di Dusun KRAJAN Desa Wringinanom Gg III RT 01 RW 05, Gresik, Jawa Timur. Waktu peneliti untuk melakukan penelitian yaitu selama lima bulan, yaitu mulai pada bulan Januari 2019 sampai Mei 2019.

\section{HASIL DAN PEMBAHASAN \\ Gerakan Lingkungan Ecoton}

Permasalahan ekologi yang terjadi di Sungai Brantas disebabkan oleh aktivitas masyarakat dan pendirian industri di wilayah bantaran sungai. Pertumbuhan ekonomi di Kawasan Surabaya memicu berbagai pendirian industri sehingga menjadi daya tarik bagi investor. Pembangunan secara besar-besaran tanpa memperhatikan keseimbangan lingkungan menimbulkan berbagai masalah ekologi. Gerakan yang muncul dari Ecoton merupakan respon atas kerusakan yang terjadi pada Sungai Brantas.

Gerakan sosial yang dilakukan Ecoton dapat dikategorikan sebagai sebuah gerakan sosial baru. Hal ini ditunjang dengan fakta-fakta bahwa dalam gerakan sosial yang dilakukan Ecoton terdapat unsur-unsur yang dapat dilihat sebagai Gerakan Sosial Baru Menurut (Singh: 2010). Dalam gerakan sosial baru mempunyai empat ciri sebagai berikut : Pertama, Gerakan sosial harus memiliki tujuan yang jelas dan ideologi yang kuat untuk menjadi dasar dalam menjalankan gerakan. Konsep Ideologi dalam Gerakan Sosial Baru (GSB) menurut (Singh, 201 0:125) adalah pertahanan diri komunitas dan masyarakat untuk melawan meningkatnya ekspansi dari negara. Yang mana dalam Laclau dan Mouffe menyebutkan yang termasuk dalam GSB salah satunya adalah ekologi, dengan medan perjuangannya bergerak pada industri dan pabrik. GSB pada dasarnya merupakan bentuk respon terhadap hadir dan menguatnya dua institusi yang menerobos masuk ke hampir semua relung kehidupan masyarakat yakni negara dan pasar. Ecoton lahir memperjuangkan pengawasan dan kontrol sosial pada pemerintah dengan melawan tata sosial dan kondisi yang didominasi oleh negara dan menyerukan sebuah kondisi yang lebih adil dan bermartabat. Pada penelitian ini Ideologi yang dipegang oleh Ecoton adalah kepedulian pada lingkungan yang mengalami kerusakan. Munculnya Ecoton didasari oleh kondisi lingkungan Sungai Brantas yang telah tercemar dikarenakan adanya perilaku antroposentris yang terjadi pada masyarakat dan pemerintah. Ecoton berupaya menyadarkan masyarakat dan juga pemerintah agar lebih memperahtikan permasalahan yang terjadi di Sungai Brantas. Sejak Ecoton didirikan ideologi kepedulian terhadap Sungai Brantas menjadi pengangan utama dan selalu ditanamkan kepada seluruh aktivis yang ada didalamnya. Bermula dari ideologi inilah yang kemudian menciptakan berbagai kegiatan dalam upaya pemulihan Sungai Brantas.

Nilai-nilai dan etika lingkungan menjadi dasar dalam ideologi hijau yang memandang manusia dan alam sederajat. Pandangan biosentrisme yang menempatkan alam mempunyai nilai dalam dirinya tanpa memikirkan kepentingan manusia lebih ditekankan Ecoton. Sungai Brantas bagi Ecoton adalah alam yang harus disetarakan dengan manusai tidak melulu di kesampingkan. Ecoton menempatkan dirinya adalah sebagai kepanjangan tangan Sungai Brantas yang tidak bisa mengungkapkan kondisinya yang semakin hari kian kritis akibat perilakua manusia yang menjadikan sungai sebagai tempat sampah. Ideologi biosentrisme ini dapat digunakan sebagai akar untuk menganalisa persoalan sumberdaya dan lingkungan. Perilaku manusia yang sekarang ini lebih memandang manusia adalah makhluk hidup yang 
mempunyai kepentingan atas alam mulai diluruhkan dengan memberikan pengetahuan akan kondisi Sungai Brantas yang dalam keadaan tercemar.

Usaha menumbuhkan kesadaran masyarakat dan memberikan peran kepada masyarakat dalam penyelamatan lingkungan hidup Jawa Timur adalah salah satu tujuan Ecoton dalam menjalankan gerakannya. Selama ini manusia memperlakukan lingkungan berlandaskan pada ideologi antroposentris. Sehingga cara pandang antroposentris ini mempengaruhi manusia hanya memanfaatkan dan mengeksploitasi sumberdaya air. Pandangan seperti ini bukan untuk pemanfaatan sumberdaya dengan bertanggung jawab namun sekedar untuk memenuhi kebutuhan manusia yang mengarah pada pemuasaan hidup. Ecoton mempunyai harapan suapay masyarakat memiliki kecintaan terhadap alam semesta terutama Sungai Brantas untuk menjaga kelestarian ekosistemnya serta memanfaatkan sungai dengan bijak. Bukan sekedar mengekspolitasi sungai melainkan perasaan saling memiliki untuk bisa menjaga harus tertanam dalam jiwanya. Membuat masyarakat menyadari arti penting Sungai Brantas dan juga memiliki rasa memiliki terhadap Sungai Brantas, sehingga perubahan-perubahan yang terjadi tidak merusak kelestarian Sungai Brantas yang pada akhirnya nanti akan merugikan manusia sendiri.

Ecoton adalah gerakan sosial baru yang memberikan perubahan kepada masyarakat tentang pengetahuan dan kesadaran terhadap lingkungan. dengan menuntut suatu etika baru yang tidak berpusat pada manusia, namu berpusat kepada makhluk hidup secara keseluruhan dalam kaitannya dengan upaya mengatasi persoalan lingkungan itulah yang dilakukan oleh Ecoton. Ideologi yang diusung oleh Ecoton lebih memperhatikan isu nilai dan etika lingkungan, hal ini menjadi cermin bahwa Ecoton adalah gerakan sosial baru yang memberikan perubahan kepada masyarakat Jawa Timur tentang pengetahuan dan kesadaran terhadap lingkungan. prespektif deep ecology menjadi tuntutan bagi Ecoton dalam beraksi memperjuangkan fenomena lingkungan menuju perubahan mencapai keberhasilan. Menuntut suatu etika baru yang tidak berpusat pada manusia, namun berpusat kepada makhluk hidup secara keseluruhan dalam kaitannya dengan upaya pemulihan Sungai Brantas. Manusia dan kepentingannya bukan lagi sebagai ukuran bagi segala sesuatu yang lain. Seharusnya memutuskan kepentingan untuk seluruh kelompok lingkungan yaitu memusatkan perhatian pada seluruh jenis ekosistem. Etika moral ini harus diwujudkan dalam aksi nyata sebagai sebuah gerakan yang lebih berpihak kepada Sungai Brantas dan memandang lingkungan harus diperlakukan selayaknya manusia. Sehingga mewujudkan manusia-manusia yang mempunyai nilai kecintaan pada alam untuk saling menjaga. Tujuan dari gerakan Ecoton adalah meningkatkan kesadaran dan peran serta masyarakat dalam penyelamatan lingkungan hidup Jawa Timur, membangun kerjasama dengan semua stakeholder dalam meningkatkan kualitas lingkungan hidup di Jawa Timur dan memajukan pengimplementasian pembanguan berkelanjutan yang berwawasan lingkungan di Jawa Timur.

Kedua, Suatu gerakan sosial mengalami perkembangan dengan memperhatikan sisfatsifat yang ada dalam suatu masyarakat. Permasalahan lingkungan menjadi landasan untuk melakukan gerakan sosial. Strategi yang dikembangkan oleh Ecoton diarahkan untuk memperkuat gerakan dalam mencapai tujuan. Dalam melakukan gerakan lingkungan, Ecoton mempunyai strategi yang menjadi penopang dalam setiap gerakannya. Dalam gerakannya yang telah dijabarkan diatas Ecoton mempunyai 3 tahapan diantaranya adalah penelitian pastisipastif, edukasi dan juga advokasi. Penelitian dilakukan untuk menghasilkan data yang valid dan scientifif atas kondisi kerusakan lingkungan beserta penyebab dan dampak yang nyata terjadi pada Sungai Brantas. Dengan data yang dihasilkan tersebut akan menjadi dasar pada gerakan-gerakan selanjutnya. Melihat pada gerakan lingkungan Indonesia yang barubaru muncul di tahun 78-an, mengangkat isu mengenai penumpukan merkuri di Teluk Jakarta 
serta polusi udara dari cerobong-cerobong asap pabrik-pabrik semen di daerah Jakarta. Gerakan yang dilakukan oleh Kelompok Sepuluh adalah melakukan riset dengan mengumpulkan contoh air laut dan ikan, kemudian mengirimnya ke laboratorium swasta yang terpercaya untuk diuji kandungan merkurinya dan mengirimkan hasil-hasilnya ke media. Hingga hasil test kesehatan yang dilakukan yang menunjukkan bahwa penyakit Minamata telah menyerang sebagian warga nelayan Teluk Jakarta yang disebkan oleh merkuri.

Kemudian, gerakan Ecoton selanjutnya adalah melakukan advokasi yang menjadi tindaklanjut dari kegiatan penelitian. Hal yang cukup krusial dan menjadi kekuatan dari sisi kontribusi pada lahirnya perubahan kebijakan adalah advokasi. Kebijakan menurut (Budiman, 1996: 89) merupakan keputusan-keputusan publik yang diambil oleh negara dan dilaksanakan oleh apparat birokrasi. Prosesnya meliputi tujuan-tujuan negara dan cara pengambilan keputusannya, orang-orang atau kelompok-kelompok yang dilibatkan, dan bagaimana kebijakan ini dilaksanakan oleh aparat birokrasi. Dalam kutipan (Gamson, 1975), (Porta dan Diani, 1999: 228) menyebutkan keberhasilan gerakan sosial dapat dilihat dari perubahan nyata kebijakan publik untuk merespon tuntutan dan protes. Gerakan advokasi menjadi sangat penting karena untuk mendorong terwujudnya perubahan atas ketidakadilan kondisi lingkungan yang mengarah pada pembuatan kebijakan oleh pemerintah. Bukti-bukti yang dikumpul dari hasil penelitian menjadi kekuatan dari gerakan advokasi. Pada gerakan Ecoton bekerjasama LBH (Lembaga Bantuan Hukum) dalam proses advokasi. Awal yang dilakukan oleh Ecoton dalam gerakan advokasi adalah mengirim surat somasi kepada pemerintah terkait atas kerusakan lingkungan yang terjadi berdasarkan hasil penelitian yang dilakukan. Karena tidak ada tanggapan yang lebih lanjut dari Pemerintah barulah Ecoton melakukan Gugatan kepada Pemerintah yang memiliki diskresi untuk membuat kebijakan baru berdasarkan undang-undang. Gerakan advokasi Ecoton dilakukan secara sistematis sesuai dengan prosedur hukum. Gerakan advokasi yang dilakukan Ecoton sama seperti WALHI pada tahun 1988 yang memberikan mandatnya kepada YLBHI (Yayasan Lembaha Bantuan Hukum Indonesia) untuk mengajukan tuntutan hukum terhadap lima lembaga pemerintah ditambah satu perusahaan swasta, yaitu kasus PT Inti Indorayon Utama. Pada tahun tersebut adalah pertama kalinya Ornop-Ornop Indonesia menuntut Pemerintah berdasarkan pada Undang-Undang Pengelolaan Lingkungan tahun 1986 serta peraturan pelaksanaanya, peraturan ANDAL (Analisis Dampak Lingkungan).

Sebagai gerakan lingkungan, Ecoton melakukan edukasi pada masyarakat di sekitar daerah aliran Sungai Brantas karena menjadi bagian dari strateginya dalam pemulihan Sungai Brantas. Masyarakat adalah bagian penting dalam menjaga kelestarian Sungai Brantas, sehingga Ecoton memberikan edukasi berupa pengetahuan dan juga peran agar masyarakat bisa membetuk komunitas-komunitas yang berperan aktif dalam pengawasan dan perencanaan, serta menjadi bagian penting dari pengelolaan sumber-sumber air. Penjaga sekaligus perusak lingkungan adalah manusia itu sendiri. Oleh karena iti kesadaran masayarakat untuk menjaga lingkungan harus ditanamkan, apabila kesadaran telah ada maka akan muncul rasa tanggung jawan untuk menjaga lingkungan. Anak-anak juga dilibatkan dalam pemulihan Sungai Brantas dengan melakukan pendidikan lingkungan. Anak Usia SD rata-rata berumur 6 tahun sampai 12 tahun, di usia ini anak memiliki masa perkembangan yang sudah mempunyai kemampuan berpikir dan telah mempunyai kemerdekaan mereka. Memberikan pengetahuan dan edukasi tentang lingkungan pada usia ini akan mempengaruhi karakter manusia yang peduli akan kelestarian lingkungan. Pada saat usia dini, anak-anak mudah dididik menurut kemauan pendidikannya. Pendidikan lingkungan memiliki peran yang strategis dan penting dalam mempersiapkan manusia untuk memecahkan masalah- 
masalah lingkungan. Pendidikan lingkungan bertujuan untuk mendorong dan membentuk manusia yang yang mampu berpartisipasi dan melaksanakan upaya pelestarian lingkungan dan pembangunan berkelanjutan bagi kepentingan generasi sekarang maupun akan datang.

Setiap melakukan tiga tahapan gerakan tersebut Ecoton menggandeng media massa untuk menyalurkan informasi mengenai apa yang mereka lakukan, seperti dalam hal penelitian mengenai pembedahan ikan Kali Surabaya. Setelah melakukan penelitian, hasil penelitian membuktikan adanya mikoplastik yang terkandung pada Ikan Kali Surabaya kemudian diinformasikan kepada masyarakat melalui media massa, baik melalui media cetak maupun online. Hal itu dilakukan Ecoton untuk memberikan informasi mengenai kondisi lingkungan yang terjadi pada ekosistem di Sungai Brantas dengan harapan memberikan kesadaran pada masyarakat untuk lebih peduli pada lingkungan. Dibuktikan juga dengan situs berita elektronik lingkungan seperti mongabay yang telah meliput kegiatan Ecoton sejak tahun 2012 sampai sekarang sudah terdapat 84 berita yang memberikan informasi kegiatan yang telak dilakukan ecoton. Pelibatan media massa dalam gerakan lingkungan sudah dilakukan pada masa orde baru Soeharto pada saat peringatan Hari Lingkungan 1978. Saat itu terbentuknya koalisi organaisasi non pemerintah yaitu kelompok sepuluh pelestari lingkungan hidup yang digerakkan oleh Walhi (Wahana Lingkungan Hidup). Kampanye anti polusi yang dilakukan untuk menghentikan polusi pabrik kimia kerjasama dengan Jepang di dekat Semarang, dan polusinya kemungkinan berasal dari pembangkit tenaga nuklir pertama di Indonesia. Berkat kampanye yang menggandeng media massa Indonesia dan Jepang selama setahun berhasil menutup pabrik kimia Diamond yang menyebabkan polusi.

Ecoton juga mempunyai strategi untuk membuat aksi demostrasi yang menarik dan unik. Pada aksi ikan bencong, Ecoton menampilkan laki-laki memakai bra warna-warni dan atribut ikan seperti putri duyung. Dengan memaki kostum tersebut sebagai representas ikan Kali Surabaya yang mengalami perubahan seksual (ikan bencong) karena pencemaran sir sungai. adanya aksi ini membuat perhatian masyarakat untuk melihat dan mengetahui permasalahan yang terjadi di Sungai Brantas. Serta membentangkan poster dengan tulisan yang lucu seperti "mandar mugo sing mbuwak popok nang kali, cepet tuwek, utange akeh, tambah lemu, ngentutan". Atribut dan aksesoris yang digunakan Ecoton dalam setiap aksinya yang selalu menjadi perhatian masyarakat.

Ketiga, Berbeda dengan gerakan sosial klasik menurut (Singh, 2010:129) struktur gerakan sosial baru didefinisikan oleh pluralitas cita-cita, tujuan kehendak dan orientasi dan heterogenitas basis sosial. Masyarakat di masa lalu mereproduksikan dirinya dengan terbatas, ada batasan-batasan dari hukum alam dan juga meta sosial. Pada gerakan Ecoton mempunyai struktur dengan berbagai macam tujuan dan menyuarakan beragam masalah lingkungan. Gerakan sosial baru mengorganisasi dalam gaya yang mengalir dan tidak kaku untuk menghindari bahaya olgarkisasi. Menciptakan struktur yang lebih responsive kepada kebutuhan-kebutuhan individu, yakni struktur yang terbuka, terdesentralisasi dan nonhirarkis. Struktur yang dibangun Ecoton tidak mementingkan kekuasaan atau kepemimpinan formal sehingga struktur yang digunakan Ecoton non-institusioanl. Ecoton tidak memiliki konsep kepemimpinan yang hirakri atau adanya pergantian pemimpin secara teratur. Gerakan Ecoton sebagai gerakan lingkungan yang merupakan bagian dari gerakan sosial baru lebih menganut terhadap struktur yang felksibel, hal ini dapat terlihat dari kepemimpinan Prigi Arisandi sebagai Direktur Eksekutif Ecoton dalam menjalankan kegiatannya bersama aktivis lingkungan lainnya. Prigi Arisandi sebagai Direktur eksekutif terbentuk secara kesepakatan kolektif. Beliau menjadi pemimpin karena sebagai penggagas Ecoton.

Struktur yang dibangun oleh Ecoton adalah bentuk refleksi dari pemerintah yang mengabaikan kondisi Sungai Brantas. Kegiatan pencemaran yang marak dilakukan industri- 
industri terjadi karena kurangnya pengawasan dari pemerintah. Dalam strukturnya Ecoton mempunyai divisi yang bekerja secara integral karena Ecoton menganggap bahwa isu yang dikerjakan pada setiap divisi sangat berkaitan satu sama lain. Pembagian kerja pada staf Ecoton sesuai dengan struktur yang dibangun. Struktur yang mengatur gerak gerik Ecoton nantinya, setiap individu didalamnya saling menghormati masing-masing dan memastikan bahwa gerakan individu sesuai dengan tujuan dan visi misi dari Ecoton itu sendiri. Sebagai contoh adalah manager advokasi dan litigasi bertugas melakukan segala proses advokasi hukum melalui proses pengadilan dengan mengumpulkan data-data dari manger peneliti. Pada manager advokasi ini mempunyai dua staf advokat yang sudah mempunyai izin resmi dalam melakukan advokasi.

Ecoton mengorganisasi diri mereka dalam gaya yang mengalir dan tidak kaku untuk menghindari bahaya oligarkisasi. Ecoton membangun struktur yang merefleksikan pemerintah yang mengabaikan pencemaran. Ecoton menciptakan struktur yang lebih responsif terhadap permasalahan-permasalahan yang terajadi pada Sungai Brantas. Dengan tidak mementingkan kekuasaan ataupun kepemimpinan formal, konsep organisasi yang dibangun Ecoton tidak merujuk pada struktur, melainkan menoak struktur organisasi yang hirarkis dan lebih memilih untuk pengambilan keputusan secara kolektif. Ecoton lebih menekankan untuk menjalankan komitmen kebersamaan sesuai misi dan tujuan awalnya.

Keempat, Aktor-aktor gerakan sosial baru berasal dari berbagai basis sosial yang melintasi kategori-kategori sosial seperti gender, pendidikan, okupasi dan kelas. Tidak terkotak-kotakkan pada penggolongan tertentu seperti kaum proletar, petani, dan buruh. Para aktor gerakan sosial baru berjuang melintasi sekat-sekat sosialnya demi kepentingan manusia (Singh, 2010:132). Para aktor Ecoton adalah semua pegawai Ecoton yang terdiri dari berbagai gender dan pendidikan. Pegawai Ecoton yang beraktifitas dalam gerakan sosial baru mempunyai tujuan yang sama dalam pelestarian lingkungan. Latar belakang kelas dalam gerakan sosial baru tidak menentukan identitas dari para aktor.

Aktor di Ecoton baik pengurus maupun Pembina memiliki ikatan yang sama rata akan tetapi ada pengutamaan atau pembagian divisi berdasarkan pengalaman atau jenis ilmu yang dimiliki individu masing-masing. Direktur eksekutif Ecoton merupakan aktor yang menjadi penggerak staf ecoton maupun penggerak masyarakat dalam pemulihan sungai. Banyak gagasan maupun dorongan yang diberikan sehingga memunculkan kegiatan-kegiatan pelestarian Sungai Brantas.

Pada perjalanan gerakan sosial baru yang dilakukan, Ecoton memiliki partisipan dari berbagai kelompok bukan hanya para pegawainya saja. Partisipan Ecoton terdiri dari pelajar, mahasiswa, kelompok pkk, komunitas lingkungan, kelompok petani hutan yang berasal dari kelas sosial yang berbeda. Alasan partsipan bergabung dalam gerakan Ecoton adalah karena mempunya semangat dan tujuan yang sama untuk menjaga dan melestarikan alam. Partsipan gerakan merupakan inti kekuatan dari aksi yang dijalankan oleh Ecoton. Partisipasi sangat penting untuk mendorong Ecoton dalam melakukan geraknnya. Partisipan tidak hanya berasal dari kalangan yang berstatus sosial yang sama melainkan dari bermacam kalangan yang nantinya memberikan kontribusi yang sama bagi gerakan untuk pencapaian tujuan kepentingan bersama.

Partisipan Ecoton bisa dibedakan menjadi dua sifat yaitu bersifat sebagai pegawai/aktivis, yaitu mereka yang masuk dalam struktur organisasi Ecoton dan mempunyai kegiatan yang sudah terorganisir. Aktivis Ecoton biasanya mempunyai program sesuai dengan bidangnya merespon masalah yang terjadi pada Sungai Brantas. Kedua adalah volunteer yaitu mereka yang hanya berpartisipasi dan datang pada kegiatan yang didakan oleh Ecoton. Untuk memperluas pastisipasi volunteer, Ecoton membuka pendaftaran secara 
online melalui sosial media Ecoton. Dengan membuka kesempatan bagi, mahasiwa, umum, seluruh penggiat untuk berpartisipasi dalam setiap kegiatan Ecoton.

\section{KESIMPULAN}

Dari uraian rumusan masalah yang telah dijelaskan, maka penulis akan menguraikan inti dari setiap uraian bab sebelumnya. Kesimpulan dari rumusan masalah tersebut adalah :

1) Permasalahan di Sungai Brantas terjadi pada bagin hulu hingga ke muara sungai. alih fungsi lahan di wilayah hulu semakin marak terjadi karena jumlah penduduk di Jawa Timur yang mengalami peningkatan. Kebutuhan atas lahan merubah fungsi hutan menjadi pemukiman dan lahan pertanian. Mendirikan bangunan di bantaran sungai juga menjadi pilihan masyarakat karena dianggap sebagai solusi. hingga menimbulkan banyak dampak lingkungan yang merusak ekosistem dan kualitas Sungai Brantas. Pencemaran Domestik tak bisa dihentikan karena perilaku manusia yang menganggap sungai adalah tempah pembuangan sehingga menjadi budaya. Pembuangan sampah domestik yang paling banyak dibuang di sungai adalah sampah popok bayi, hal ini karena mitos yang berkembang di masyarakat Jawa Timur. Perkembangan industri memunculkan pendirian perusahaan-perusahaan dalam berbagai bidang di Jawa Timur. Seiring berjalannya industri menyebabkan pencemaran di Sungai Brantas karena pengelolaan limbah industri yang tidak dilakukan sesuai dengan prosedur. Akibat banyaknya pencemaran dari industri terutama industri gula menimbulkan masalah baru yaitu ikan mati massal. Permasalahan yang terjadi di Sungai Brantas ini disebakan oleh masyarakat dan juga berdampak pada masyarakt itu sendiri. Sehingga mendorong gerakan lingkungan yang mucul dari Ecoton untuk mengajak masyarakat Jawa Timur untuk peduli terhadap lingkungan serta berperan aktif dalam pelaksanaan pelestarian lingkungan yang berkelanjutan.

2) Gerakan yang dilakukan Ecoton dalam Pemulihan Sungai Brantas meliputi tiga gerakan. Pertama adalah melakukan penelitian partisipatif yang lebih menonjolkan kondisi biologis sungai. Dalam penelitiannya Ecoton mengajak masyarakat untuk meneliti permasalahan yang terjadi di Sungai Brantas dan menginformasikan hasil penelitian yang sudah dilakukan kepada masyarakat melalui media. Kedua adalah edukasi lingkungan. hasil penelitian yang sudah dilakukan dijadikan sebagai dasar pengetahuan dalam melakukan edukasi pada masyarakat sehingaa mendorong masyarakat untuk membentuk komunitas yang berperan aktif dalam pengelolaan sungai Brantas. Serta mengajak anak-anak sekolah sebagai generasi penerus pelestari lingkungan. Ketiga adalah Advokasi. gerakan advokasi ini dilakukan untuk mendorong terwujudnya perubahan atas ketidakadilan kondisi lingkungan sehingga memunculkan kebijakan publik yang mendukung mengenai perlindungai kelestarian lingkungan.

\section{DAFTAR PUSTAKA}

Agustiningsih, Sasongko, Sudarno. 2012. "Analisis Kualitas Air dan Strategi Pengendalian Pencemaran Air Sungai Blukar Kabupaten Kendal" Jurnal Presipitasi Media Komunikasi dan Pengembangan Teknik Lingkungan Vol 9 No 2, 64-71. https://ejournal.undip.ac.id/index.php/presipitasi/article/viewFile/4928/4465 Diakses pada 23 Nov 2018

Anandriyo Suryo Mratihatani. 2013. Menuju Pengelolaan Sungai Bersih di Kawasan Industri Batik Yang Padat Limbah Cair. (Studi Empiris : Watershed Sungai Pekalongan di 
Kota Pekalongan). Fakultas Ekonomika dan Bisnis Jurusan Ilmu Ekonomi Studi Pembangunan Universitas Diponegoro.

Bect, Manuel, Salvador, dkk. 2013. "The use of urban wastewater for the Colorado River delta restoration" Journal Procedia Environmental Sciences 18, 829-835.

Della Porta, Donatella and Mario Diani. 1999. Social Movements: An Introduction. Oxford: Blackwell.Development: Case Studie From Indonesia. Leiden: CNWS.diakses pada tanggal 9 Desember 2018 di

Erfan Nilasmani. 2009. Peranan Lembaga Swadaya Masyarakat Ecoton Dalam Menanggulangi Pencemaran Di Kali Surabaya (Studi Kasus Di Lsm Ecoton). Fakultas Hukum Jurusan Perdata Universitas Muhammadiyah Malang.

Junus, George Aditjondro. 2003. Pola-Pola Gerakan Lingkungan. Yogyakarta: Pustaka Pelajar.

Kuemmerlen, Peter, dkk. 2018. "Ecological assessment of river networks: From reach to catchment scale" Journal Science of the Total Environment 650, 1613-1627.

Made, Pande Kutanegara. 2012. Manusia, Lingkungan dan Sungai. Yogyakarta: UGM Pers

Maryono, Agus. 2017. Reformasi Pengelolan Sumber Daya Air. Yogyakarta: Gajah mada University Press.

Mochamad Riszal Pratama. 2015. Kampanye Sosial Tentang Kesadaran Lingkungan (Studi Pada Lembaga Swadaya Masyarakat Lingkungan Ecoton Gresik). Fakultas Dakwah Dan Komunikasi Jurusan Komunikasi Universitas Islam Negeri Sunan Ampel Surabaya.

Novianti, Kurnia. 2013. Peran NGO sebagai Bagian dari Civil Society dalam Mitigasi Banjir di Praha. Global \& Strategis. Th. 7, No. 2. LIPI : Jakarta.

Pusarperdal. 2011. Fakta Pengelolaan Sungai Indonesia. Jakarta: Kementerian Lingkungan Hidup.

Quina, Margaretha. 2017. Cls Sebagai Salah Satu Instrumen untuk Mendorong Laju Pemulihan Sungai: Pembelajaran dari Sungai Gangga dan Riachuelo. Jurnal hukum Indonesia Vol. 3 Issue 2. diakses pada tanggal 8 Desember 2018 di https://icel.or.id/wp-content/uploads/Jurnal-HLI-Vol.-3-Issue-2-Maret-2017.pdf

Salam, Burhan Fauzi. 2018. Upaya Restorasi Daerah Aliran Sungai dengan Pemanfaatan Lahan Basah Buatan". PSLP. Universitas Brawijaya.

Singgih Hermanto, 2015. Menyelamatkan Kali Mas di Surabaya. Fakultas Sastra Jurusan Ilmu Sejarah Uiversitas Jember.

Singh, Rajendra. 2010. Gerakan Sosial Baru. Yogyakarta: Resist Book.

Sudaryanti, S. 1997. Prosiding Pelatihan Strategi Pemantauan Kualitas Air Sungai Secara Biologis, Fakultas Perikanan Universitas Brawijaya. Malang.

Sugiyono. 2010. Metode Penelitian Pendidikan Pendekatan Kuantitatif, Kualitatif, dan $R$ \& $D$, Bandung: Alfabeta.

Tommy, 2018, Popok, Limbah Berbahaya yang Cemari Sungai-sungai di Jawa, Mongabay, di akses pada 2 September 2018.

Wahib, Abdul Situmorang. 2013. Dinamika Protes Kolektif Lingkungan Hidup di Indonesia (1968-2011). Yogyakarta: Pustaka Pelajar.

Widodo, Kasam, dkk. 2013. "Strategi Penurunan Pencemaran Limbah Domestik di Sungai Code DIY" Jurnal Sains dan Teknologi Lingkungan Volume 5, Nomor1 hal. 36-47.

Wijayanto, 2018, Hilir Brantas Tercemar Limbah Industri, Radar Surabaya, di akses pada 25 Juli 2018. 